\title{
PENGARUH RISK ATTITUDES TERHADAP KINERJA PERUSAHAAN MELALUI KEPUTUSAN PENEMPATAN MODAL KERJA (Studi Pada Usaha Kecil dan Menengah (UKM) di Pulau Lombok)
}

\author{
Siti Aisyah Hidayati ${ }^{1}$, Sri Wahyulina ${ }^{2}$, Harmi Widiana ${ }^{3}$ \\ ${ }^{l}$ Fakultas Ekonomi dan Bisnis Unram, hidayati250573@yahoo.com \\ ${ }^{2}$ Fakultas Ekonomi dan Bisnis Unram, sriwahyulina@yahoo.co.id \\ ${ }^{3}$ Fakultas Ekonomi dan Bisnis Unram, harmiwidiana@yahoo.com
}

\begin{abstract}
ABSTRAK
Penelitian ini bertujuan untuk menganalisis: 1) pengaruh risk attitudes terhadap keputusan penempatan dana untuk modal kerja pada UKM, 2) pengaruh risk attitudes terhadap kinerja perusahaan pada UKM, 3) pengaruh keputusan penempatan dana untuk modal kerja terhadap kinerja perusahaan pada UKM, dan 4) pengaruh risk attitudes terhadap kinerja perusahaan melalui keputusan penempatan dana untuk modal kerja pada UKM.

Populasi penelitian adalah semua UKM di Pulau Lombok. Teknik pengambilan sampel dilakukan dengan non probability sampling, yaitu menggunakan judgment sampling. Sampel yang diambil UKM yang bergerak pada industri gerabah dan sudah melakukan ekspor. Responden penelitian ini manajer sekaligus pemilik UKM. Metode analisis data yang digunakan Generalized Structured Component Analysis.

Hasil penelitian menunjukkan risk attitudes berpengaruh signifikan terhadap kinerja perusahaan melalui keputusan investasi penempatan dana untuk modal kerja. Selain itu juga bisa dikatakan bahwa secara psikologis manajer sekaligus pemilik UKM rasional dalam pengambilan keputusan investasi (penempatan dana untuk modal kerja). Hal ini dilatarbelakangi oleh sebagian besar manajer sekaligus pemilik UKM laki-laki, berusia masih produktif dan berpengalaman dibidangnya lebih dari 10 tahun.
\end{abstract}

Kata Kunci: risk attitudes, modal kerja, kinerja perusahaan

\section{ABSTRACT}

This study aimed to analyze: 1) the influence of risk attitudes against the decision of placement of funds for working capital to SMEs, 2) influence risk attitudes to company performance on SMEs, 3) the effect of the decision of placement of funds for working capital to the company performance in SME, and 4) risk attitudes influence on the performance of the company through placement decisions funds for working capital to SMEs.

The study population was all SMEs in Lombok Island. The sampling technique is done by non-probability sampling, using judgment sampling. Samples taken SMEs engaged in the pottery industry and is already exporting. This study respondent's owner managers of SMEs. Data analysis methods used Generalized Structured Component Analysis

The results showed risk attitudes significantly influence the company's performance through the investment decision placement of funds for working capital. It also can be said that psychologically owner managers of SMEs rational investment decision (placement of funds for working capital). This is motivated by the majority of SME owner manager's men, aged are still productive and experienced in their fields more than 10 years.

Keywords: risk attitudes, working capital, company performance 


\section{PENDAHULUAN}

Keuangan perilaku (behavioural finance) pada dasarnya mempelajari aspek pengambilan keputusan dalam bidang keuangan. Pada pengambilan keputusan di bidang keuangan, terdapat kemungkinan terjadinya bias. Oleh karena itu, peluang studi keuangan perilaku tidak dibatasi pada studi di pasar modal atau perusahaan yang saat ini cenderung mendominasi studi keuangan perilaku. Perilaku manajer dan pemilik perusahaan baik yang berorientasi pada laba maupun nirlaba, aparat pemerintah dan rumah tangga yang berkenaan dengan keputusan keuangan ternyata belum banyak disentuh sehingga jarang menemukan referensi berupa hasil studi yang dimuat di berbagai jurnal ilmiah. Padahal para pengambil keputusan tersebut juga dimungkinkan tidak sepenuhnya rasional atau yang disebut oleh Thaler (1994) dalam Supramono, Kaudin, Mahastuti dan Damayanti (2010:18) sebagai quasy rational. Oleh karena itu, lingkup penelitian keuangan perilaku perlu diperluas. Berdasarkan pelaku pengambilan keputusan, lingkup keuangan perilaku dapat dikelompokkan menjadi empat kategori meliputi perilaku investor di pasar modal, perilaku manajer dalam pengambilan keputusan keuangan, perilaku aparatur pemerintah dalam pengelolaan keuangan negara dan perilaku rumah tangga dalam pengelolaan keuangan (Supramono, dkk., 2010:18). Berdasarkan hal tersebut, Usaha Kecil dan Menengah (UKM) termasuk dalam objek yang dapat diteliti dengan melihat perilaku manajer dalam pengambilan keputusan dan merupakan financial institution (Gumanti, 2009:8).

Risk attitudes merupakan salah satu aspek dalam behavioral finance yang menurut Tversky and Brack (1995) merupakan perilaku manusia yang bertentangan dengan asumsi-asumsi yang mendasari model ekonomi klasik dalam pengambilan keputusan. Fenomena ini disebut sebagai cognitive illusions, karena terkait dengan persepsi yang seringkali dapat menimbulkan error. Pengambilan keputusan berdasarkan cognitive illusions banyak berpedoman pada irrationality sedangkan model ekonomi klasik banyak berpedoman pada rationality. Pertentangan inilah yang menjadi theory gap dalam penelitian ini. Asumsi mendasar dalam teori ekonomi menganggap bahwa manusia merupakan makhluk yang tidak menyukai risiko. Tidak menyukai risiko adalah hal yang lazim, tetapi asumsi seperti ini tidak berlaku untuk semua situasi (Tversky and Brack, 1995:3). Terdapat hubungan positif antara tingkat risiko dan tingkat keuntungan yang diharapkan oleh investor. Investor yang bersikap tidak menyukai risiko (risk averse) menjadi tidak rasional dengan bersedia mengambil suatu kesempatan investasi yang lebih berisiko apabila mereka mendapatkan tingkat keuntungan yang lebih tinggi.

Usaha Kecil dan Menengah (UKM) di Pulau Lombok masih dihadapkan dengan permasalahan mentalitas dalam pengambilan keputusan oleh manajer sekaligus pemilik UKM terutama yang berkaitan dengan pengelolaan keuangan. Berbagai faktor kelemahan internal yang memengaruhi kinerja dan keberhasilan atau kegagalan usaha kecil dan menengah diantaranya ketidakmampuan di dalam manajemen, lemahnya kemampuan dalam pengambilan keputusan, kurang pengalaman, lemahnya pengawasan keuangan, serta skala usaha yang terlalu kecil (Idrus, 1999:18). Selain itu, ada satu hal yang sering terabaikan, yaitu mentalitas pengusaha UKM (www.diskop.padang.go.id). Hal ini berkaitan dengan behavioural financial pengusaha UKM dalam pengambilan keputusan. Permasalahan mentalitas dalam pengambilan keputusan juga dialami oleh manajer-manajer UKM yang ada di pulau Lombok. Hal ini disebabkan karena kepemilikan UKM didominasi oleh perorangan, sehingga pertimbangan-pertimbangan 
dalam pengambilan keputusan yang dilakukan banyak berdasarkan intuisi yang dimiliki oleh manajer UKM yang sekaligus sebagai pemiliknya.

Keputusan investasi dalam modal kerja pada UKM merupakan hal yang penting, karena UKM mempunyai akses yang terbatas pada modal yang bersifat jangka panjang (Weston dan Copeland, 1986:277). Keputusan investasi pada UKM terkait dengan keputusan bagaimana pengusaha UKM menempatkan dananya pada aktiva lancar, yaitu kas, piutang dan persediaan. Keputusan investasi akan mempengaruhi kinerja keuangan suatu perusahaan dapat dilihat pada penelitian yang dilakukan oleh Caballero, Teruel dan Solano (2011) yang menyatakan bahwa ada hubungan yang kuat antara investasi pada modal kerja dengan kinerja perusahaan. Menurut penelitian tersebut, walaupun terbatasnya pengujian terhadap investasi modal kerja dihubungkan dengan nilai perusahaan, ide tentang pengaruh manajemen modal kerja terhadap nilai perusahaan dapat diterima secara umum.

\section{TUJUAN PENELITIAN}

\section{Penelitian ini bertujuan untuk:}

1. Menganalisis pengaruh risk attitudes terhadap keputusan penempatan dana untuk modal kerja pada UKM.

2. Menganalisis pengaruh risk attitudes terhadap kinerja perusahaan pada UKM.

3. Menganalisis pengaruh keputusan penempatan dana untuk modal kerja terhadap kinerja perusahaan pada UKM.

4. Menganalisis pengaruh risk attitudes terhadap kinerja perusahaan melalui keputusan penempatan dana untuk modal kerja pada UKM.

\section{TINJAUAN PUSTAKA DAN HIPOTESIS}

\subsection{TINJAUAN PUSTAKA}

\subsubsection{Pengertian Behavioural Finance}

Menurut De Bondt, et al. (2008:7) menyatakan "Behavioral finance is the study

of how psychology impacts financial decisions in households, market and organizations", yang artinya studi tentang bagaimana psikologi berdampak pada keputusan-keputusan keuangan di dalam rumah tangga, pasar dan organisasi. Sedangkan menurut Pompian (2006:4) Behavioral Finance, commonly defined as the application of psychology to finance. Shefrin's (2005) dalam Forbes (2009:1) Behavioral finance is the study of how psychological phenomena impact financial behavior. Sedangkan menurut Lintner (1998:7), behavioural finance "the study of humans interprets and act on information to make informed investment decisions" artinya, keuangan perilaku merupakan ilmu yang mempelajari bagaimana manusia menginterpretasikan dan bertindak terhadap informasi untuk membuat keputusan dalam berinvestasi. Jadi unsur sikap dan tindakan manusia merupakan faktor penentu dalam berinvestasi. Sehingga Behavioural finance, secara sederhana dapat didefinisikan sebagai aplikasi dari psikologi ke dalam disiplin ilmu keuangan dalam pengambilan keputusan keuangan di dalam rumah tangga, pasar dan organisasi. 
Ricciardi dan Simon (2000) dalam Gumanti (2009:8) membagi tiga kelompok individu yang memiliki kepentingan baik secara langsung/tidak langsung terhadap behavioural finance:

1. Individual, yang terdiri dari small investor, portfolio manager, pension board

2. Group, yang terdiri dari investor reksadana (portfolio)

3. Organization, misalnya financial institution, non-profit organization

Isu sentral yang ditelaah oleh behavioural finance mencakup pertanyaan "mengapa investor dan manajer keuangan melakukan kesalahan sistematis dalam mengambil keputusan investasi?". Selain itu behavioural finance juga menjelaskan perilaku beberapa pihak dan pelaku pasar yang mengambil keuntungan dari ketidakefisienan pasar melalui perilaku arbitrage. Behavioural finance juga menitikberatkan pada beberapa bentuk ketidakefisienan pasar. Reaksi yang keliru dari para pelaku pasar disebabkan oleh kesalahan penilaian, overconfidence/ overoptimism dan berbagai kesalahan lainnya yang ditimbulkan oleh psychological bias.

\subsubsection{Teori-teori Behavioural Finance}

Ricciardi dan Simon (2000) dalam Gumanti, (2009:9) membagi empat tema utama yang tercakup dalam keuangan perilaku.

a. Overconfidence Theory

Keyakinan berlebihan sudah menjadi salah satu topik menarik yang mendapatkan perhatian luas dari para peneliti dibidang psikologis dan keuangan perilaku. Sebagai manusia, tidak dapat disangkal bahwa pengusaha atau manajer memiliki kecenderungan untuk terlalu yakin atas kemampuan dan prediksi untuk berhasil. Kondisi ini merupakan hal yang normal yang sekaligus merupakan cermin dari tingkat keyakinan seseorang untuk mencapai atau mendapatkan sesuatu. Keyakinan yang berlebihan juga muncul dari sudut pandang bidang pemasaran.

b. Financial Cognitive Dissonance Theory

Teori ketidakberaturan kognitif keuangan (financial cognitive dissonance) yang dikembangkan oleh Festinger dalam Morton (1993) dalam Gumanti (2009:10), menyatakan bahwa manusia merasakan tekanan internal dan keraguan atau ketakutan manakala dihadapkan pada benturan atau perbedaan keyakinan. Sebagai individu, sebaiknya mencoba untuk mengurangi konflik internal yang ada pada diri (mengurangi dissonance) setidaknya dengan satu dari dua cara berikut, yaitu (1) merubah nilai masa lalu, perasaan atau opini, dan (2) mencoba untuk merasionalisasi pilihan-pilihan.

c. Regret Theory

Teori penyesalan (regret theory) menyatakan bahwa individual melakukan evaluasi reaksi harapan pada suatu kejadian atau situasi di masa depan. Bell (1982) menggambarkan penyesalan (regret) sebagai emosi yang disebabkan oleh perbandingan pada suatu keluaran tertentu (a given outcome) atau suatu kejadian dengan sesuatu yang tidak jadi dipilih (foregone choice).

d. Prospect Theory

Teori prospek (prospect theory) berkaitan dengan ide bahwa manusia tidak selalu berperilaku secara rasional. Teori ini beranggapan bahwa ada bias yang melekat dan terus ada yang dimotivasi oleh faktor-faktor psikologi yang mempengaruhi pilihan orang dibawah kondisi ketidakpastian. Teori prospek mempertimbangkan preferensi sebagai suatu fungsi timbangan-timbangan keputusan dan berasumsi bahwa timbangan-timbangan keputusan dan berasumsi bahwa timbangan-timbangan tersebut tidak selalu tepat dengan probabilitas. Secara spesifik, teori prospek 
berpendapat bahwa timbangan-timbangan cenderung lebih tinggi daripada probabilitas yang rendah dan lebih rendah daripada probabilitas yang moderat atau tinggi.

Selain dari keempat teori diatas, ada teori lain yang bisa menjelaskan risk attiudes yaitu Teori Manfaat Harapan (Expected Utility) yang diperkenalkan oleh Bernoulli pada abad ke 18. Teori ini mengatakan bahwa tidak semua orang pasti akan memilih alternatif yang sama. Tergantung pada sikap masing-masing individu terhadap risiko. Teori Manfaat Harapan menyangkut pemilihan rasional alternatif keputusan yang menekankan bahwa orang mempunyai perilaku yang berbeda terhadap risiko. Sebagian orang berperilaku penghindar risiko dan berupaya untuk memaksimalkan manfaat dari setiap keputusan yang diambil. Bagi seorang yang berperilaku demikian, kurva fungsi manfaat berbentuk cekung, menunjukkan tambahan manfaat yang menurun untuk setiap tambahan pengeluaran. Sebagian yang lain bersikap netral terhadap risiko dengan kurva manfaaat yang berbentuk linier, serta sebagian yang lain lagi berperilaku penyuka risiko dengan kurva manfaat yang berbentuk cembung, menunjukkan peningkatan tambahan manfaat untuk setiap tambahan pengeluaran (Asri, 2013:32-33).

Karena itu, literatur psikologi menjuluki konsep manfaat harapan ini sebagai konsep yang menggambarkan harapan moral (moral expectation), bukan sekedar "harapan" yang dihitung secara matematis (mathematical expectation). Namun masih ada yang menganggap teori expected utility terlalu menyederhanakan permasalahan karena menganggap bahwa keputusan yang diambil seseorang seolah-olah hanya ditentukan oleh sikapnya terhadap risiko.

\subsection{HIPOTESIS}

H1 : Risk attitudes berpengaruh terhadap keputusan penempatan dana untuk modal kerja pada UKM.

H2 : Risk attitudes berpengaruh terhadap kinerja perusahaan pada UKM.

H3 : Keputusan penempatan dana untuk modal kerja berpengaruh terhadap kinerja perusahaan pada UKM.

H4 : Risk attitudes berpengaruh terhadap kinerja perusahaan melalui keputusan penempatan dana untuk modal kerja pada UKM.

\section{METODE PENELITIAN}

\subsection{Pendekatan Penelitian}

Penelitian ini merupakan penelitian berbasis pendekatan kuantitatif, dengan jenis penelitian explanatory research yang menganalisis pengaruh satu variabel terhadap variabel lainnya. Penelitian ini menganalisis risk attitudes terhadap kinerja perusahaan melalui keputusan penempatan dana untuk modal kerja pada UKM di Pulau Lombok.

\subsection{Lokasi Penelitian}

Penelitian ini dilakukan pada UKM gerabah yang melakukan ekspor di Pulau Lombok.

\subsection{Populasi Penelitian}

Populasi penelitian adalah semua UKM di Pulau Lombok yang berjumlah 64.536 unit (Dinas Perindustrian dan Perdagangan Prov. NTB, 2016). 


\subsection{Teknik Pengambilan sampel}

Teknik pengambilan sampel dilakukan dengan non probability sampling, yaitu menggunakan judgment sampling yaitu memilih sampel dengan pertimbangan tertentu. Sampel yang diambil adalah UKM yang bergerak pada industri kerajinan gerabah dan sudah melakukan ekspor. Pertimbangan yang digunakan dalam pemilihan UKM tersebut adalah kegiatan memproduksi dan menjual gerabah terutama untuk ekspor ditentukan oleh faktor psikologis yang ada pada diri manajer sekaligus pemilik UKM seperti pertimbangan risiko. Sampel yang dapat diambil dari populasi yang ada adalah 29 UKM yang berada di Pulau Lombok.

\subsection{Unit Analisis}

Unit analisis penelitian adalah UKM yang bergerak pada usaha gerabah dan sudah melakukan ekspor berjumlah sebanyak 29 UKM yang berada di Pulau Lombok. Responden dalam penelitian ini adalah manajer yang sekaligus pemilik dari tiap-tiap UKM tersebut.

\subsection{Variabel Penelitian}

Penelitian ini menggunakan dua jenis variabel, yaitu variabel eksogen dan variabel endogen.

1. Variabel eksogen yaitu risk attitudes.

2. Variabel endogen penelitian ini adalah penempatan dana untuk modal kerja dan kinerja perusahaan.

\subsection{Definisi Operasional Variabel}

\subsubsection{Variabel Eksogen}

\subsubsection{Risk Attitudes}

Risk attitudes adalah sikap manajer terhadap risiko yang dihadapi. Ada 5 (lima) indikator yang dapat digunakan pada penelitian ini dan bersifat refleksif. Indikator dan item yang dimaksud ditunjukkan dalam Tabel 1.

Tabel 1.

Indikator dan Item Variabel Risk Attitudes

\begin{tabular}{|c|c|c|}
\hline No. & Indikator & Item \\
\hline 1 & $\begin{array}{l}\text { Betting on self creation (melakukan kreasi } \\
\text { sendiri): menghasilkan produk dengan kreasi } \\
\text { sendiri }\end{array}$ & $\begin{array}{l}\text { 1. Pemilik sekaligus manajer UKM yakin } \\
\text { pembeli menyukai produk yang } \\
\text { merupakan kreasinya } \\
\text { 2. Pemilik UKM yakin bahwa produk } \\
\text { yang dihasilkan akan laku } \\
\text { 3. Pemillik UKM yakin bahwa produk } \\
\text { yang dihasilkan akan diminati orang }\end{array}$ \\
\hline 2. & $\begin{array}{l}\text { Capitalizing on opportunities (memanfaatkan } \\
\text { peluang): memanfaatkan kesempatan (peluang) } \\
\text { usaha yang ada untuk melakukan sesuatu dengan } \\
\text { tidak mempertimbangkan risiko yang ada }\end{array}$ & $\begin{array}{l}\text { 1. Pemilik UKM selalu memanfaatkan } \\
\text { kesempatan (peluang) usaha yang } \\
\text { datang } \\
\text { 2. Pemilik UKM yakin kesempatan } \\
\text { (peluang) usaha yang ada } \\
\text { menguntungkan } \\
\text { 3. Pemilik UKM selalu merasa } \\
\text { kesempatan (peluang) usaha tidak akan } \\
\text { datang dua kali }\end{array}$ \\
\hline 3. & Buying (Pembelian): Pembelian yang dilakukan & 1. Pemilik UKM selalu melakukan \\
\hline
\end{tabular}

24 | Pengaruh risk attitudes terhadap kinerja Perusahaan melalui keputusan... 


\begin{tabular}{|c|c|c|}
\hline No. & Indikator & Item \\
\hline & yang berkaitan dengan usaha yang dijalankan & $\begin{array}{l}\text { pemeriksaan secara detail terhadap } \\
\text { bahan/perlengkapan yang sudah dibeli } \\
\text { 2. Pemilik UKM selalu merasa pembelian } \\
\text { yang dilakukan sudah sesuai dengan } \\
\text { kebutuhan }\end{array}$ \\
\hline 4. & $\begin{array}{l}\text { No fear of losses (tidak takut mengalami } \\
\text { kerugian): tidak takut terhadap kerugian yang } \\
\text { akan timbul dalam menjalankan usaha }\end{array}$ & $\begin{array}{l}\text { 1. Pemilik UKM yakin kerugian yang } \\
\text { dialami adalah pelajaran berharga dan } \\
\text { tidak akan terjadi lagi } \\
\text { 2. Pemilik UKM merasa bisa } \\
\text { mengantisipasi kerugian yang akan } \\
\text { timbul }\end{array}$ \\
\hline 5. & $\begin{array}{l}\text { Stable returns (pendapatan yang stabil): } \\
\text { pendapatan yang diterima dari hasil usaha relatif } \\
\text { tidak berfluktuasi }\end{array}$ & $\begin{array}{l}\text { 1. Pemilik UKM yakin dengan produk } \\
\text { yang dihasilkan akan diperoleh } \\
\text { pendapatan yang stabil } \\
\text { 2. Pemilik UKM yakin risiko yang akan } \\
\text { datang tidak selalu berpengaruh } \\
\text { terhadap pendapatan }\end{array}$ \\
\hline
\end{tabular}

\subsubsection{Variabel Endogen}

\subsubsection{Penempatan Dana untuk Modal Kerja}

Penempatan dana untuk modal kerja diukur dengan menggunakan indikatorindikator yang bersifat refleksif. Adapun indikator dan itemnya ditunjukkan dalam Tabel 2.

Tabel 2. Indikator dan Item Variabel Penempatan Dana untuk Modal Kerja

\begin{tabular}{|c|c|c|}
\hline No. & Indikator & Item \\
\hline 1. & Efficiency of Cash Management (ECM) & $\begin{array}{l}\text { 1. Persiapan anggaran kas } \\
\text { 2. Penentuan saldo kas yang ingin dicapai } \\
\text { 3. Penghitungan jumlah kas yang seharusnya tersedia }\end{array}$ \\
\hline 2. & $\begin{array}{l}\text { Efficiency of Receivables Management } \\
\text { (ERM) }\end{array}$ & $\begin{array}{l}\text { 1. Persiapan pedoman kredit untuk pelanggan } \\
\text { 2. Memeriksa tingkat piutang } \\
\text { 3. Memeriksa tingkat kredit macet }\end{array}$ \\
\hline 3. & $\begin{array}{l}\text { Efficiency of Inventory Management } \\
\text { (EIM) }\end{array}$ & $\begin{array}{l}\text { 1. Persiapan anggaran persediaan } \\
\text { 2. Memeriksa tingkat persediaan } \\
\text { 3. Mengantisipasi ketidaktepatan jumlah persediaan }\end{array}$ \\
\hline
\end{tabular}

\subsubsection{Kinerja Perusahaan}

Kinerja perusahaan merupakan tolok ukur keberhasilan perusahaan, yang meliputi indikator financial dan indikator non financial. Indikator-indikator kinerja perusahaan UKM bersifat formatif. Adapun indikator dan itemnya ditunjukkan dalam Tabel 3.

Tabel 3. Indikator dan Item Variabel Kinerja Perusahaan

\begin{tabular}{|c|c|c|}
\hline No. & Indikator & Item \\
\hline 1. & Kinerja Financial & $\begin{array}{l}\text { 1. Rasio Keuntungan bersih terhadap investasi } \\
\text { 2. Rasio keuntungan bersih terhadap penjualan } \\
\text { 3. Pertumbuhan Penjualan }\end{array}$ \\
\hline 2. & Kinerja Non Financial & $\begin{array}{l}\text { 1. Pengembangan produk baru } \\
\text { 2. Peningkatan pasar } \\
\text { 3. Pengembangan sumberdaya manusia }\end{array}$ \\
\hline
\end{tabular}




\subsection{Pengukuran Variabel}

\subsubsection{Pengukuran Variabel eksogen}

Skala Likert digunakan untuk mengukur variabel eksogen, yaitu Risk Attitudes. Variabel yang akan diukur dijabarkan menjadi indikator. Hubungan antar variabel tersebut di atas dirumuskan dalam hipotesis penelitian yang akan diuji kebenarannya. Dengan kata lain penelitian ini bertujuan untuk menguji hipotesis. Pengukuran variabel ini dilakukan dengan skala Likert yang dituangkan dalam bentuk pilihan jawaban angket, yaitu: a. Sangat tidak setuju (skor 1); b. Tidak Setuju (skor 2); c. Netral (Skor 3); d. Setuju (skor 4); e. Sangat setuju (skor 5).

\subsubsection{Pengukuran Variabel Endogen}

\subsubsection{Untuk mengukur variabel penempatan dana untuk modal kerja}

Pengukuran variabel penempatan dana untuk modal kerja dilakukan dengan skala Likert. Adapun skor skala yang digunakan adalah: a. Sangat tidak setuju (skor 1); b. Tidak setuju (skor 2); c. Netral (skor 3); d. Setuju (skor 4); Sangat setuju (skor 5)

\subsubsection{Untuk mengukur variabel Kinerja Perusahaan}

Pengukuran variabel kinerja perusahaan, baik yang financial maupun non financial dilakukan juga dengan skala Likert yang diadopsi dari penelitian Jermias and Gani (2005). Adapun skor skala yang digunakan adalah: a. Sangat rendah (skor1); b. Rendah (skor 2); c. Sedang (skor 3); d. Tinggi (skor 4); e. Tinggi sekali (skor 5)

\subsection{Jenis dan Sumber Data}

Jenis data yang digunakan dalam penelitian ini adalah: Data Kualitatif, seperti sikap manajer keuangan dalam pengambilan keputusan yang berkaitan dengan risk attitudes dan persepsi manajer keuangan terhadap penempatan dana untuk modal kerja dan kinerja perusahaan. Sumber Data yang digunakan adala Data primer, yaitu data yang diperoleh langsung dari obyek penelitian, yang berupa jawaban dari pernyataan yang ada di angket.

\subsection{Teknik Pengumpulan Data}

Teknik pengumpulan data yang digunakan dalam penelitian survei ini adalah dengan menggunakan angket, yaitu daftar yang mencakup semua pernyataan yang akan digunakan untuk mendapatkan data yang dilakukan melalui bertatap muka.

\subsection{Alat Analisis}

Untuk mencapai tujuan penelitian serta pengujian hipotesis, maka data yang diperoleh akan diolah sesuai dengan kebutuhan analisis. Di dalam penelitian ini, data yang telah diperoleh akan diuji dengan menggunakan Generalized Structured Component Analysis (GSCA). GSCA dikembangkan oleh Heungsun Hwang, Hec Montreal dan Yhoshio Tahane pada tahun 2004. Tujuannya adalah menggantikan faktor dengan kombinasi linier dari indikator (variabel manifest) dalam analisis SEM. Pendekatan analisis ini menggunakan metode kuadrat terkecil (least square) di dalam proses pendugaan parameter. GSCA dikembangkan untuk menghindari kekurangan dari PLS (partial least square), yaitu dilengkapi dengan prosedur optimalisasi global dan juga dapat diterapkan pada hubungan antar variabel yang kompleks (bisa rekursif dan tidak rekursif), melibatkan higher-order komponen (faktor) dan perbandingan multi-group (Solimun, 2012). 


\section{HASIL PENELITIAN DAN PEMBAHASAN}

\subsection{Karakteristik Responden}

Data responden menunjukkan 37,9 persen responden berusia antara 37 dan 45 tahun, 24 persen responden berusia lebih dari 54 tahun, 17,2 persen berusia antara 45 dan 54 tahun, 13,8 persen menunjukkan usia 30 sampai 37 tahun dan sisanya 6,9 persen berada pada kisaran umur $22-29$ persen. Ditinjau dari usianya, sebagian besar manajer UKM di Pulau Lombok berada pada usia produktif. Artinya, para manajer UKM tersebut mempunyai kemampuan fisik untuk bekerja dan memiliki potensi berpikir dan bertindak secara efekif sehingga diharapkan dapat meningkatkan kinerja perusahaan.

Karakteristik responden berdasarkan jenis kelamin menunjukkan sebagian besar responden yaitu 72,4 persen berjenis kelamin laki-laki, sedangkan sisanya yaitu 27,6 persen berjenis kelamin perempuan. Artinya pengambil keputusan pada UKM industri gerabah di Pulau Lombok sebagian besar berjenis kelamin laki-laki, sehingga bisa dikatakan keberlangsungan usaha banyak didominasi kaum laki-laki selaku manajer sekaligus pemilik perusahaan. Hal ini terjadi karena pengelola UKM adalah kepala rumah tangga.

Karakteristik responden dilihat dari tingkat pendidikan menunjukkan sebagian besar tamatan SMA, yaitu sebesar 44,8 persen, sedangkan, tamatan Perguruan Tinggi dan SD mempunyai persentase yang sama yaitu 28,6 persen. Hal ini menunjukkan pendidikan para manajer berada pada tingkatan menengah yang akan berpengaruh dalam pengambilan keputusan.

Karakteristik responden berdasarkan jumlah karyawan yang dimiliki menunjukkan sebagian besar responden, yaitu 78,6 persen, memiliki karyawan tetap sampai dengan 10 orang. Jumlah ini memang sesuai dengan kriteria jumlah karyawan pada Usaha Kecil. Apabila ada pesanan dalam jumlah yang besar biasanya pemilik UKM menambah jumlah karyawannya. Dengan kata lain, perusahaan akan melakukan penambahan jumlah karyawan sewaktu-waktu apabila dibutuhkan.

Karakteristik responden dilihat dari lamanya usaha menunjukkan 39,2 persen sudah berusaha antara 10 dan 15 tahun, 28,6 persen antara 15-20 tahun, 14,3 persen dari responden sudah menjalankan usaha antara 5 dan 10 tahun atau lebih dari 20 tahun dan yang menjalankan usaha kurang dari 5 tahun sebanyak 3,6 persen. Kondisi ini mencerminkan sebagian besar responden atau 82,1 persen sudah melangsungkan usahanya lebih dari 10 tahun. Hal ini menunjukkan manajer sekaligus pemilik UKM sudah banyak pengalaman dalam pengelolaan usaha yang dimiliki.

\subsection{Hasil Analisis Generalized Structured Component Analysis}

Metode analisis data yang digunakan dalam penelitian ini adalah Generalized Structured Component Analysis (GSCA). GSCA adalah model persamaan struktural (SEM) yang berbasis komponen atau varian (variance), Dalam penelitian ini, pengujian model struktural dan hipotesis penelitian dengan melihat nilai koefisien jalur dari variabel eksogen ke endogen dan melihat nilai signifikansi. Pengujian model struktural dalam GSCA dilakukan melalui resampling bootstrap. Evaluasi model struktural dan hipotesis bertujuan untuk mengetahui seberapa besar informasi yang dapat dijelaskan oleh model struktural (hubungan antara variabel laten). Lebih jelasnya uraian analisis dan evaluasi model pada GSCA penelitian ini sebagai berikut: 


\subsubsection{Measure of Fit Structural Model}

Measure of Fit Structural Model diukur menggunakan FIT, yaitu setara dengan $\mathrm{R}^{2}$ pada analisis regresi atau koefisien determinasi total pada analisis jalur atau $\mathrm{Q}^{2}$ pada PLS, FIT menunjukkan varian total dari semua variabel yang dapat dijelaskan oleh model struktural. Nilai FIT berkisar dari 0 sampai 1, semakin besar nilai ini, semakin besar proporsi varian variabel yang dapat dijelaskan oleh model. Jika nilai FIT $=1$ berarti model secara sempurna dapat menjelaskan fenomena yang diselidiki. AFIT (Adjusted FIT) serupa dengan $\mathrm{R}^{2}$ adjusted pada analisis regresi. AFIT dapat digunakan untuk perbandingan model. Model dengan AFIT nilai terbesar dapat dipilih antara model yang lebih baik (Solimun, 2012).

Tabel 4. Hasil Pengujian Measure of fit Structural Model

\begin{tabular}{|c|c|}
\hline \multicolumn{2}{|c|}{ Model Fit } \\
\hline FIT & 0,692 \\
\hline AFIT & 0,668 \\
\hline
\end{tabular}

Hasil pengujian Measure of Fit Structural Model berdasarkan Tabel 4. memperlihatkan bahwa proporsi varian variabel yang dapat dijelaskan oleh model adalah sebesar 69,2\% atau keragaman Risk Attitudes, keputusan penempatan dana untuk modal kerja dan kinerja perusahaan dijelaskan oleh model adalah sebesar 69,2\%. Sedangkan 30,8\% dijelaskan oleh faktor-faktor lain, seperti: volume penjualan, faktor musim dan siklus, perubahan dalam teknologi dan kebijakan perusahaan. Berarti model ini cukup baik untuk menjelaskan fenomena yang dikaji.

\subsubsection{Measurement Model Masing-masing Variabel}

Measurement Model diukur berdasarkan nilai loading factor (standardize coefficient) pada setiap indikator ke variabel laten. Nilai loading factor menunjukkan bobot setiap faktor sebagai pengukur masing-masing variabel. Indikator dengan loading factor terbesar menunjukkan bahwa indikator tersebut sebagai pengukur variabel dominan (terkuat).

Tabel 5. Hasil Pengujian Model Pengukuran Variabel Risk Attitudes

\begin{tabular}{|c|c|c|c|c|c|c|c|c|c|}
\hline Variable & \multicolumn{3}{|c|}{ Loading } & \multicolumn{3}{|c|}{ Weight } & \multicolumn{3}{|c|}{ SMC } \\
\hline & Estimate & SE & CR & Estimate & SE & $\mathbf{C R}$ & Estimate & SE & CR \\
\hline $\mathrm{X1}$ & & & & $\mathrm{VE}=0.76$ & Alpha & $=0.91$ & & & \\
\hline X11 & 0.892 & 0.047 & $18.84^{*}$ & 0.214 & 0.044 & $4.86^{*}$ & 0.795 & 0.082 & $9.7^{*}$ \\
\hline $\mathrm{X} 12$ & 0.881 & 0.046 & $19.14^{*}$ & 0.268 & 0.040 & $6.62^{*}$ & 0.776 & 0.078 & $9.98^{*}$ \\
\hline $\mathrm{X13}$ & 0.915 & 0.030 & $30.81^{*}$ & 0.184 & 0.048 & $3.87^{*}$ & 0.837 & 0.054 & $15.65^{*}$ \\
\hline X1.4 & 0.880 & 0.046 & $19.22^{*}$ & 0.253 & 0.040 & $6.38^{*}$ & 0.775 & 0.079 & $9.81^{*}$ \\
\hline $\mathrm{X} 1.5$ & 0.802 & 0.071 & $11.28^{*}$ & 0.227 & 0.044 & $5.15^{*}$ & 0.643 & 0.108 & $5.93^{*}$ \\
\hline
\end{tabular}

Keterangan: $\mathrm{CR}^{*}=$ Signifikan pada $\alpha=0,05$

Hasil komputasi model pengukuran variabel risk attitudes (X1) pada Tabel 5 menunjukkan bahwa kelima indikator valid digunakan dalam merefleksikan pengukuran variabel risk attitudes. Dibuktikan dengan nilai loading estimate kelima indikator variabel secara keseluruhan memiliki nilai lebih besar dari 0,70 dan nilai CR signifikan 
pada tingkat kepercayaan $95 \%$. Mencerminkan bahwa korelasi di antara semua indikator variabel positif dan signifikan dalam merefleksikan variabel laten.

Hasil analisis data, jika dilihat dari nilai loading estimate yang diperoleh untuk masing-masing indikator, indikator buying adalah paling dominan dalam merefleksikan variabel risk attitudes. Nilai loading estimate pada indikator buying paling besar di antara keempat indikator lainnya yakni sebesar 0,915 , diikuti indikator betting on self creation sebesar 0,047 , capitalizing on opportunities sebesar 0,881 , no fear of losses sebesar 0,880 dan terkecil indikator stable returns. Selain itu, dengan nilai titik kritis $(C R)$ yang diperoleh, indikator buying dapat digunakan untuk mengukur variabel risk attitudes karena diperoleh nilai terbesar 30,81 signifikan pada tingkat kepercayaan $\alpha=$ 0,05 dibandingkan dengan keempat indikator yang lain.

Nilai AVE (Average Variance Extracted) sebesar 0,765. Apabila dibandingkan nilai square root of AVE yang dimiliki indikator risk attitudes dengan nilai korelasi antar variabel laten lainnya dalam model bisa dikatakan variabel ini memiliki discriminant validity yang baik, karena nilai square root of $A V E$ nya lebih besar dibandingkan dengan nilai korelasi seluruh variabel laten lainnya. Dengan demikian, instrumen penelitian yang digunakan untuk mengukur variabel risk attitudes memenuhi kriteria validitas diskriminan. Hasil analisis data dengan metode GSCA menunjukkan nilai alpha yang diperoleh sebesar 0,910 , yang artinya variabel risk attitudes memiliki konsistensi reliabilitas internal yang baik karena lebih besar dari 0,6.

Hasil pengujian menunjukkan manajer sekaligus pemilik UKM berani mengambil risiko dalam pembelian bahan/perlengkapan untuk usahanya. Pada saat melakukan pembelian, mereka selalu melakukan pemeriksaan secara detail terhadap bahan/perlengkapan yang sudah dibeli.

Tabel 6. Hasil Pengujian Model Pengukuran Variabel Penempatan

Dana untuk Modal Kerja (Y1)

\begin{tabular}{|c|c|c|c|c|c|c|c|c|c|c|}
\hline Variable & \multicolumn{3}{|c|}{ Loading } & \multicolumn{3}{c|}{ Weight } & \multicolumn{3}{c|}{ SMC } \\
\hline & Estimate & SE & CR & Estimate & SE & CR & Estimate & SE & CR \\
\hline \multicolumn{9}{|c|}{ AVE $=\mathbf{0 . 7 8 8 , ~ A l p h a ~}=\mathbf{0 . 8 3 4}$} \\
\hline Y1 & \multicolumn{9}{|c|}{. } \\
\hline Y11 & 0.894 & 0.036 & $24.84^{*}$ & 0.340 & 0.064 & $5.34^{*}$ & 0.798 & 0.063 & $12.72^{*}$ \\
\hline Y12 & 0.863 & 0.055 & $15.61^{*}$ & 0.428 & 0.053 & $8.11^{*}$ & 0.746 & 0.095 & $7.82^{*}$ \\
\hline Y13 & 0.905 & 0.027 & $33.72^{*}$ & 0.361 & 0.088 & $4.09^{*}$ & 0.820 & 0.048 & $16.94^{*}$ \\
\hline
\end{tabular}

Keterangan: $\mathrm{CR}^{*}=$ Signifikan pada $\alpha=0,05$

Variabel keputusan investasi/penempatan dana untuk modal kerja (Y1) mempunyai 3 indikator dengan 9 pernyataan. Indikator pertama, yaitu Efficiency of Cash Management (ECM), dengan 3 pernyataan. Indikator kedua yaitu Efficiency of Receivables Management (ERM) dengan 3 pernyataan dan indikator ketiga, Efficiency of inventory management (EIM) memiliki 3 pernyataan.

Pengujian model pengukuran variabel keputusan investasi (penempatan dana untuk modal kerja) pada Tabel 6 diperoleh bahwa nilai estimate loading ketiga variabel secara keseluruhan memiliki nilai CR signifikan pada $\alpha=0,05$. Artinya ketiga indikator yang digunakan valid untuk merefleksikan pengukuran variabel penempatan dana untuk modal kerja. Hasil analisis mencerminkan pula bahwa korelasi antara semua indikator variabel positif dan signifikan dalam merefleksikan variabel keputusan investasi (penempatan dana untuk modal kerja). Hasil pengujian nilai loading estimate yang 
diperoleh setiap indikator, indikator EIM memiliki peran dominan dalam merefleksikan variabel keputusan investasi (penempatan dana untuk modal kerja). Nilai rata-rata loading estimate indikator EIM paling besar di antara kedua indikator yang lainnya yakni sebesar 0,905. Selanjutnya secara berturut-turut dikuti oleh indikator ERM dan $E C M$. Selain itu dapat dibuktikan dengan nilai titik kritis $(C R)$ yang diperoleh, indikator EIM paling baik bila digunakan untuk mengukur variabel Penempatan Dana untuk Modal Kerja karena diperoleh nilai CR yang paling besar yaitu 33,72 signifikan pada $\alpha$ $=0,05$. Hasil pengujian juga menunjukkan adanya efisiensi dalam manajemen persediaan yang direfleksikan oleh penyediaan anggaran untuk persediaan.

Nilai AVE variabel keputusan investasi (penempatan dana untuk modal kerja) sebesar 0,788. Apabila dibandingkan nilai square root of AVE yang dimiliki indikator variabel keputusan investasi (penempatan dana untuk modal kerja) dengan nilai korelasi antar variabel laten lainnya dalam model bisa dikatakan variabel ini memiliki discriminant validity yang baik, karena nilai square root of AVE nya lebih besar dibandingkan dengan nilai korelasi seluruh variabel laten lainnya. Dengan demikian, instrumen penelitian yang digunakan untuk mengukur variabel penempatan dana untuk modal kerja memenuhi kriteria validitas diskriminan. Hasil analisis data menunjukkan nilai alpha yang diperoleh sebesar 0,834 , yang artinya variabel penempatan dana untuk modal kerja memiliki konsistensi reliabilitas internal yang baik karena lebih besar dari 0,6 . Dapat disimpulkan bahwa instrumen penelitian yang digunakan untuk pengukuran variabel penempatan dana untuk modal kerja layak untuk diterima dari ketiga indikator variabel karena memiliki kesesuaian dan keandalan yang tinggi.

Tabel 7. Hasil Pengujian Model Pengukuran Variabel Kinerja Perusahaan

\begin{tabular}{|c|c|c|c|c|c|c|c|c|c|}
\hline Variable & \multicolumn{3}{|c|}{ Loading } & \multicolumn{3}{|c|}{ Weight } & \multicolumn{3}{|c|}{ SMC } \\
\hline & Estimate & SE & CR & Estimate & SE & CR & Estimate & SE & CR \\
\hline Y2 & & & & $\mathrm{AVE}=0.0$ & Alpha & 0.944 & & & \\
\hline Y21 & 0 & 0 & 0 & 0.611 & 0.236 & $2.59^{*}$ & 0 & 0 & 0 \\
\hline Y22 & 0 & 0 & 0 & 0.414 & 0.242 & 1.71 & 0 & 0 & 0 \\
\hline
\end{tabular}

Keterangan: $\mathrm{CR}^{*}=$ Signifikan pada $\alpha=0,05$

Variabel kinerja perusahaan merupakan satu-satunya variabel yang bersifat formatif. Variabel ini mempunyai dua indikator dengan masing-masing tiga pernyataan. Variabel kinerja perusahaan paling dibentuk oleh indikator kinerja financial. Berdasarkan nilai titik kritis $(C R)$ yang diperoleh, indikator kinerja financial yang berkaitan dengan pertumbuhan penjualan dapat digunakan untuk mengukur variabel kinerja perusahaan karena diperoleh nilai titik kritis 2,59 dan signifkan pada $\alpha=0,05$.

\subsubsection{Model Struktural}

Dalam model struktural ini, diuji 4 (empat) hipotesis hubungan. Hasil pengujian hubungan antar variabel penelitian secara lengkap disajikan pada Tabel 8.

Tabel 8. Model GSCA: Pengaruh Langsung

\begin{tabular}{|l|c|c|}
\hline \multicolumn{1}{|c|}{ Hubungan Antar Variabel } & Koefisien & Keterangan \\
\hline $\begin{array}{l}\text { Risk Attitudes terhadap Keputusan Investasi } \\
\text { (Penempatan dana untuk modal kerja) }\end{array}$ & $-0,811$ & Signifikan \\
\hline Risk Attitudes terhadap Kinerja Perusahaan & $-0,012$ & Tidak Signifikan \\
\hline Keputusan Investasi (Penempatan dana untuk & 0,865 & Signifikan \\
\hline
\end{tabular}

30 | Pengaruh risk attitudes terhadap kinerja Perusahaan melalui keputusan... 


\begin{tabular}{|c|c|c|}
\hline Hubungan Antar Variabel & Koefisien & Keterangan \\
\hline modal kerja) terhadap Kinerja Perusahaan & & \\
\hline
\end{tabular}

Gambar 1

Model Struktural Penelitian

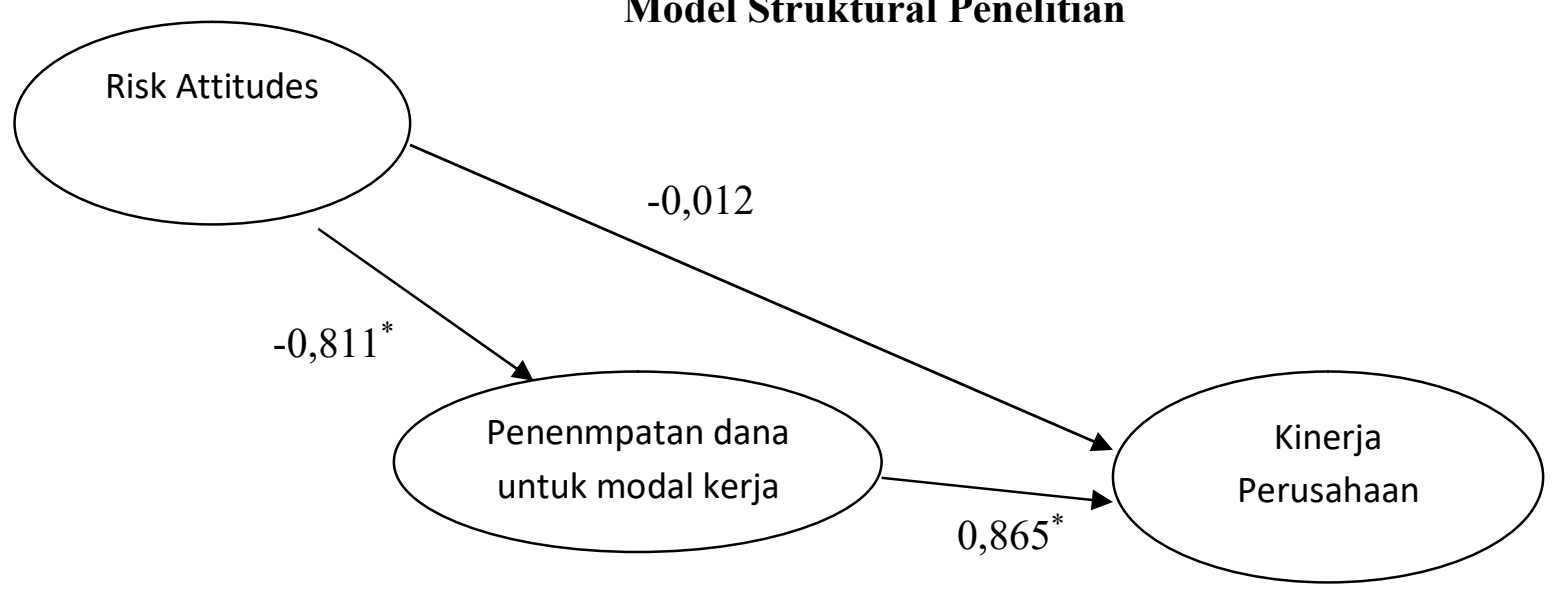

*: signifikan pada $\alpha=0$,

Pengujian hipotesis sebagai berikut:

a. Nilai koefisien pengaruh risk attitudes terhadap penempatan dana untuk modal kerja sebesar -0,811 dan signifikan, artinya semakin berani manajer UKM mengambil risiko semakin kecil modal kerja yang diinvestasikan pada usahanya.

b. Nilai koefisien pengaruh risk attitudes terhadap kinerja perusahaan sebesar -0,012 dan tidak signifikan, artinya besar kecilnya risk attitudes tidak terlalu memengaruhi besar kecilnya kinerja perusahaan. Dengan kata lain, keberanian manajer UKM mengambil risiko tidak memengaruhi besar kecilnya modal kerja yang dinvestasikan pada usahanya.

c. Nilai koefisien pengaruh keputusan investasi (penempatan dana untuk modal kerja) terhadap kinerja perusahaan sebesar 0,865 dan signifikan., artinya semakin besar modal kerja yang diinvestasikan pemilik UKM, semakin tinggi kinerja perusahaan yang diperoleh.

Perhitungan nilai koefisien pengaruh tidak langsung (indirect effect) diperoleh dari hasil perkalian 2 (dua) nilai koefisien pengaruh langsung. Pengaruh tidak langsung dinyatakan signifikan jika sudah dilakukan uji Sobel yaitu $z$ value, dihitung dengan pembagian koefisien pengaruh langsung dengan standart errornya. Hasil pengujian pengaruh tidak langsung disajikan pada Tabel 9.

Tabel 9. Hasil Pengujian Pengaruh Tidak Langsung

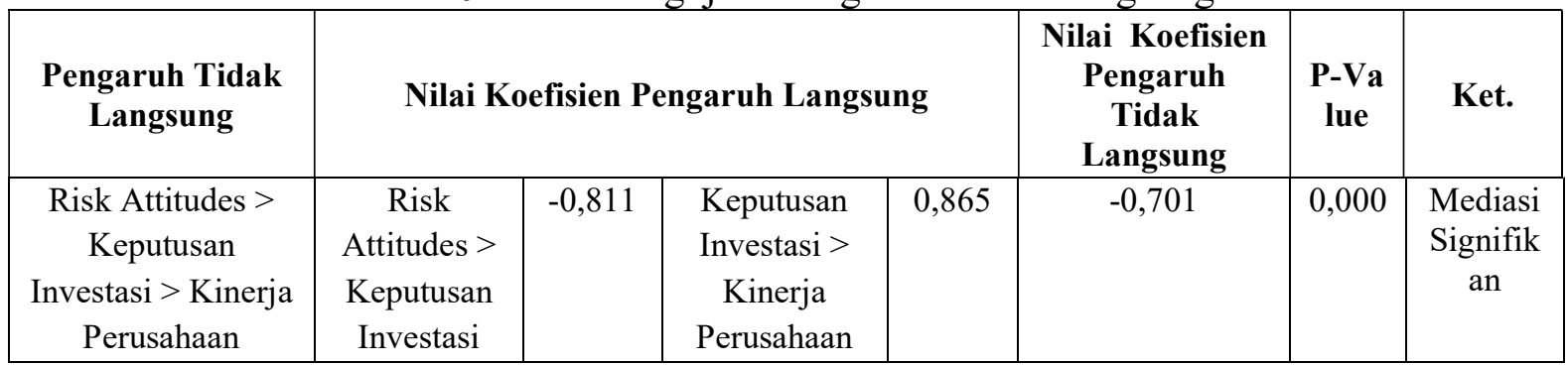

Keterangan: $>=$ terhadap 
Berdasarkan Tabel 9 dapat diuraikan hasil pengujian pengaruh tidak langsung model struktural sebagai berikut:

Berdasarkan hasil analisis pengaruh tidak langsung risk attitudes terhadap kinerja perusahaan melalui keputusan investasi (penempatan dana untuk modal kerja) diperoleh koefisien pengaruh tidak langsung sebesar $-0,701$. Karena p-value $(0,000)<\alpha(0.05)$, dapat disimpulkan terdapat pengaruh tidak langsung yang signifikan risk attitudes terhadap kinerja perusahaan melalui keputusan investasi (penempatan dana untuk modal kerja). Artinya, semakin berani manajer UKM mengambil risiko maka semakin rendah kinerja perusahaan, jika semakin kecil modal kerja yang diinvestasikan pada usahanya.

\subsection{Hubungan Antara Nilai Rerata (Mean) dan Model Pengukuran}

Hasil evaluasi responden terhadap indikator pengukuran variabel penelitian ini dicerminkan melalui nilai rerata. Evaluasi ini dimaksudkan untuk mengetahui kondisi aktual setiap indikator yang dipersepsikan responden (manajer sekaligus pemilik UKM). Nilai rerata terbesar dapat diartikan sebagai indikator yang diprioritaskan dalam pelaksanaannya menurut penilaian responden. Nilai loading estimate atau weight estimate tertinggi menunjukkan indikator pengukur variabel yang terkuat atau dapat diinterpretasikan sebagai indikator yang memiliki kontribusi dominan dalam merefleksikan/meformatifkan variabel.

Tabel 10. Rekapitulasi Nilai Loading Factor dan Rerata Indikator Variabel Risk Attitudes

\begin{tabular}{|c|l|c|c|}
\hline No & \multicolumn{1}{|c|}{ Indikator } & $\begin{array}{c}\text { Loading } \\
\text { Estimate }\end{array}$ & $\begin{array}{c}\text { Rerata } \\
\text { Indikator }\end{array}$ \\
\hline 1 & Betting on self creation & 0,892 & 4,16 \\
\hline 2 & Capitalizing on opportunities & 0,881 & 4,09 \\
\hline 3 & Buying & 0,915 & 4,03 \\
\hline 4 & No fear of losses & 0,880 & 3,94 \\
\hline 5 & Stable returns & 0,802 & 3,62 \\
\hline
\end{tabular}

Berdasarkan Tabel 10, indikator betting on self creation mempunyai nilai rerata sebesar 10, yang menunjukkan manajer UKM sudah melakukan kreasi sendiri, dengan keyakinan kreasi produk yang dihasilkan disukai dan diminati konsumen serta laku di pasaran. Nilai rerata indikator kedua, yaitu capitalizing on opportunities sebesar 4,09 yang menunjukkan bahwa manajer sudah bisa memanfaatkan peluang dengan keyakinan peluang usaha yang ada menguntungkan dan tidak datang dua kali. Indikator ketiga, yaitu buying, mempunyai nilai rerata sebesar 4,03 yang menunjukkan bahwa pembelian yang dilakukan selalu diikuti dengan pemeriksaan secara detail terhadap bahan/perlengkapan yang sudah dibeli. Indikator keempat, yaitu no fear of losses mempunyai nilai rerata sebesar 3,94 yang berarti bahwa manajer sekaligus pemilik UKM belum bisa mengantisipasi kerugian dan merasa kerugian bisa saja terulang kembali. Indikator terakhir dari variabel risk attitudes adalah stable returns, memiliki nilai rerata sebesar 3,62 yang menunjukkan pendapatan yang diterima belum dapat dikatakan stabil sehingga masih diperlukan usaha-usaha yang dapat meningkatkan pendapatan UKM. Salah satunya adalah peningkatan penjualan yang berpengaruh langsung terhadap pendapatan yang diterima.

Nilai loading estimate terbesar dimiliki oleh indikator buying sehingga dapat diambil kesimpulan variabel risk attitudes paling direfleksikan oleh indikator buying karena nilai loading estimate terbesar yaitu 0,915 dengan nilai rerata sebesar 4,03 . Hal 
ini mengindikasikan bahwa manajer UKM berani mengambil risiko pada saat melakukan pembelian dengan selalu melakukan pemeriksaan secara detail terhadap bahan/perlengkapan yang sudah dibeli.

Tabel11. Rekapitulasi Nilai Loading Factor dan Rerata Indikator Variabel Keputusan Investasi (Penempatan dana untuk modal kerja)

\begin{tabular}{|c|l|r|c|}
\hline No. & \multicolumn{1}{|c|}{ Indikator } & $\begin{array}{c}\text { Loading } \\
\text { Estimate }\end{array}$ & $\begin{array}{c}\text { Rerata } \\
\text { Indikator }\end{array}$ \\
\hline 1 & Efficiency of Cash Management (ECM) & 0,894 & 4,17 \\
\hline 2 & Efficiency of Receivables Management (ERM) & 0,863 & 4,1 \\
\hline 3 & Efficiency of Inventory Management (EIM) & 0,905 & 4,19 \\
\hline
\end{tabular}

Tabel 11 menunjukkan variabel keputusan investasi (penempatan dana untuk modal kerja) dengan 3 (tiga) indikator. Indikator pertama, yaitu ECM, memiliki nilai rerata sebesar 4,17 , artinya manajer UKM sudah melakukan persiapan anggaran kas, menentukan saldo yang ingin dicapai dan selalu melakukan perhitungan berapa jumlah kas yang seharusnya tersedia. Indikator kedua, yaitu ERM, memilki nilai rerata sebesar 4,1, artinya manajer sekaligus pemilik UKM selalu menyiapkan pedoman kredit untuk pelanggan, pemeriksaan tingkat piutang dan memeriksa tingkat kredit macet. Indikator ketiga yaitu EIM, mempunyai nilai rerata sebesar 4,19 artinya manajer sekaligus pemilik UKM sudah melakukan persiapan anggaran persediaan, memeriksa tingkat persediaan dan mengantisipasi jumlah persediaan. Dari ketiga indikator ini yang paling merefleksikan variabel Keputusan investasi (penempatan dana untuk modal kerja) adalah indikator EIM, ditunjukkan oleh nilai loading estimate yang paling besar yaitu 0,905 . Berdasarkan nilai rerata yang diperoleh masing-masing indikator, menunjukkan telah terjadi efisiensi dalam pengambilan keputusan investasi yaitu penempatan dana untuk modal kerja.

Tabel 12. Rekapitulasi Nilai Loading Factor dan Rerata Indikator Variabel Kinerja Perusahaan

\begin{tabular}{|c|l|c|c|}
\hline No. & \multicolumn{1}{|c|}{ Indikator } & Weight Estimate & $\begin{array}{c}\text { Rerata } \\
\text { Indikator }\end{array}$ \\
\hline 1 & Kinerja Financial & 0,611 & 3,99 \\
\hline 2 & Kinerja Non Financial & 0,414 & 3,33 \\
\hline
\end{tabular}

Tabel 12 menunjukkan variabel kinerja perusahaan, terdiri atas dua indikator, yaitu kinerja financial dan kinerja non financial. Kinerja financial mempunyai nilai rerata sebesar 3,99 menunjukkan kinerja financial yang dihasilkan masih sedang. Penyebabnya adalah persaingan antar UKM gerabah dalam merebut pangsa pasar yang ada. Untuk dapat meningkatkan kinerja financial perlu dtingkatkan lagi pertumbuhan penjualan. Salah satu cara yang dapat dilakukan adalah promosi melalui internet. Kinerja non financial mempunyai nilai rerata sebesar 3,33, artinya kinerja non financial yang dihasilkan juga masih sedang. Hal ini disebabkan karena kualitas sumberdaya manusia yang ada belum memadai. Pelatihan-pelatihan yang sudah diperoleh belum bisa diterapkan dalam kegiatan perusahaan.

Kinerja perusahaan paling dibentuk oleh kinerja financial dengan nilai estimate weight sebesar 0,611. Artinya, untuk dapat meningkatkan kinerja UKM yang menjadi prioritas untuk ditingkatkan adalah kinerja financial terutama peningkatan penjualan. 
Salah satu cara yang dapat dilakukan adalah promosi melalui internet, misalnya dengan membuat website atau blog. Apabila hal ini dapat dilaksanakan dengan baik maka akan tercapai kinerja UKM seperti yang diharapkan.

\subsection{Hasil Pengujian Hipotesis Penelitian}

Penelitian ini mengajukan sebanyak 4 hipotesis. Hasil penelitian menunjukkan bahwa terdapat 3 hipotesis yang diterima dan 1 hipotesis yang ditolak. Hasil pengujian hipotesis tersebut dapat diuraikan sebagai berikut:

5.4.1. Risk Attitudes Berpengaruh Signifikan terhadap Keputusan Penempatan Dana untuk Modal Kerja pada UKM

Berdasarkan hasil analisis, nilai koefisien hubungan antara risk attitudes dengan keputusan investasi (penempatan dana untuk modal kerja) adalah sebesar $-0,811$ dan signifikan pada $\alpha=0,05$ mengindikasikan bahwa pengaruh risk attitudes terhadap keputusan investasi (penempatan dana untuk modal kerja) signifikan, artinya semakin berani manajer UKM mengambil risiko, semakin kecil modal kerja yang diinvestasikan pada usahanya.

\subsubsection{Risk Attitudes Berpengaruh Tidak Signifikan terhadap Kinerja Perusahaan pada UKM}

Berdasarkan hasil analisis, koefisien hubungan antara risk attitudes dan kinerja perusahaan adalah sebesar $-0,012$ dan tidak signifikan pada $\alpha=0,05$. Hal ini mengindikasikan bahwa pengaruh risk attitudes terhadap kinerja perusahaan tidak signifikan, artinya tinggi rendahnya risk attitudes tidak terlalu memengaruhi tinggi rendahnya kinerja perusahaan. Dengan kata lain, sikap terhadap risiko manajer UKM tidak akan memengaruhi tinggi rendahnya kinerja perusahaan.

\subsubsection{Keputusan Penempatan Dana untuk Modal Kerja Berpengaruh Signifikan terhadap Kinerja Perusahaan pada UKM}

Berdasarkan hasil analisis, nilai koefisien hubungan antara keputusan investasi (penempatan dana untuk modal kerja) dengan kinerja perusahaan adalah sebesar 0,865 dan signifikan pada $\alpha=0,05$ mengindikasikan bahwa pengaruh keputusan investasi (penempatan dana untuk modal kerja) terhadap kinerja perusahaan signifikan. Artinya semakin besar modal kerja yang diinvestasikan oleh manajer UKM, semakin tinggi kinerja perusahaan yang diperoleh.

\subsubsection{Risk Attitudes Berpengaruh Signifikan terhadap Kinerja Perusahaan melalui Keputusan Penempatan Dana untuk Modal Kerja pada UKM}

Nilai koefisien hubungan antara risk attitudes dengan keputusan investasi (penempatan dana untuk modal kerja) adalah sebesar $-0,811$ dan signifikan pada $\alpha=$ 0,05 mengindikasikan bahwa pengaruh risk attitudes terhadap keputusan investasi (penempatan dana untuk modal kerja) signifikan, artinya semakin berani manajer UKM mengambil risiko, semakin kecil modal kerja yang diinvestasikan pada usahanya.

Hipotesis tersebut juga ditelusuri melalui pengujian pengaruh tidak langsung risk attitudes terhadap kinerja perusahaan melalui keputusan investasi (penempatan dana untuk modal kerja). Berdasarkan hasil analisis pengaruh tidak langsung antara risk attitudes terhadap kinerja perusahaan melalui keputusan investasi diperoleh koefisien pengaruh tidak langsung sebesar -0,443 dan signifikan, dapat disimpulkan terdapat pengaruh tidak langsung yang signifikan risk attitudes terhadap kinerja perusahaan melalui keputusan investasi. Artinya semakin berani manajer UKM mengambil risiko maka semakin rendah kinerja perusahaan, jika semakin kecil modal kerja yang diinvestasikan pada usahanya. 


\subsection{Pembahasan Hasil Penelitian}

Keberanian manajer UKM mengambil risiko diikuti dengan menurunnya penempatan dana untuk modal kerja. Hal ini disebabkan oleh adanya kesadaran dari manajer UKM tentang pengelolaan usaha yang dilakukan selama ini belum bisa dikatakan optimal, sehingga menurunkan penempatan dana untuk modal kerja. Penempatan dana untuk modal kerja di UKM yang tidak didukung oleh pengelolaan usaha yang optimal mengakibatkan kinerja perusahaan, baik yang financial maupun non financial, tidak tercapai sesuai harapan. Ada beberapa hal yang mengakibatkan pengelolaan usaha pada UKM belum bisa optimal, salah satunya adalah tingkat pendidikan sebagian besar manajer UKM adalah tingkat menengah. Hal ini mengakibatkan pengambilan keputusan yang diambil untuk penempatan modal kerja tidak diikuti kedisiplinan dalam pengaturan keuangan perusahaan dalam hal ini UKM. Secara psikologis, dilihat dari aspek affective, sikap berani mengambil risiko yang diambil oleh manajer UKM di latarbelakangi oleh mereka sebagian besar laki-laki, usia masih produktif dan berpengalaman di bidang usaha gerabah lebih dari 10 (sepuluh) tahun. Temuan ini memperluas studi tentang keuangan perilaku. Ternyata temuan penelitian yang semula dilakukan Coleman (2007), Susai and Moriyasu (2007), dan Ramiah, et al.(2012) di pasar modal sama dengan temuan hasil penelitian yang dilakukan di UKM, yaitu risk attitudes berpengaruh terhadap keputusan investasi. Lebih jelasnya, penelitian ini menghasilkan temuan bahwa risk attitudes dengan indikatorindikator: betting on self, capitalizing on opportunities, buying, no fear of losses dan stable returns berpengaruh signifikan terhadap keputusan investasi (penempatan dana untuk modal kerja).

Risk attitudes yang dimiliki oleh manajer UKM berpengaruh tidak signifikan terhadap kinerja perusahaan. Harus ada "variabel mediasi" dapat risk attitudes dapat mempengaruhi kinerja perusahaan. Pada usaha industri gerabah, sikap berani mengambil keputusan manajer UKM terhadap pembelian bahan/perlengkapan tidak akan mempengaruhi kinerja perusahaan jika sebelumnya tidak ada keputusan penempatan dana untuk modal kerja dengan mengolah bahan/perlengkapan tersebut menjadi produk gerabah. Kegiatan berikutnya adalah UKM menghasilkan produk jadi dan melakukan penjualan, barulah bisa mempengaruhi kinerja perusahaan. Hal ini berarti sikap apapun terhadap risiko yang diambil oleh manajer UKM jika tidak ada keputusan investasi penempatan dana untuk modal kerja, mempengaruhi tidak signifikan atau tidak berpengaruh terhadap kinerja perusahaan. Terbukti dengan risk attitudes apapun yang diambil oleh manajer UKM, kinerja perusahaan yang dihasilkan sedang, tidak menunjukkan penurunan atau peningkatan. Temuan ini tidak sesuai dengan hasil penelitian yang dilakukan oleh Lammers, et al. (2010), yang menyatakan risk attitudes mempunyai pengaruh dengan kinerja perusahaan. Dalam penelitian yang dilakukan oleh Lammers, et al. (2010), menunjukkan bahwa MSEs yang berupa perusahaan dagang di Lagos, Nigeria, memiliki kesadaran tentang risiko dan menangani risiko dengan hati-hati sehingga dapat menghasilkan profitabilitas yang tinggi. Sedangkan penelitian ini menggunakan sampel bukan perusahaan dagang seperti penelitian yang dilakukan Lammers, et al. (2010) tetapi perusahaan atau UKM industri gerabah yang langsung menjual sendiri produk yang dihasilkan, sehingga lebih berisiko dibandingkan dengan penelitian Lammers, et al. (2010). Selain itu, latar belakang sebagian besar responden yang mempunyai pendidikan tingkat menengah dan kepemilikan UKM yang sifatnya perorangan juga dapat mempengaruhi dalam 
pengambilan keputusan. Keputusan yang diambil seringkali dengan informasi yang terbatas dan tanpa melakukan "sharing" dengan pihak lain.

Variabel Keputusan Investasi/Penempatan dana untuk modal kerja direfleksikan oleh 3 (tiga) indikator, yaitu Efficiency of Cash Management (ECM), Efficiency of Receivables Management (ERM), dan Efficiency of Inventory Management (EIM). ECM ditunjukkan oleh manajer UKM yang sudah melakukan persiapan anggaran kas, menentukan saldo yang ingin dicapai dan selalu melakukan perhitungan berapa jumlah kas yang seharusnya tersedia. ERM ditunjukkan manajer UKM dengan selalu menyiapkan pedoman kredit untuk pelanggan, pemeriksaan tingkat piutang dan memeriksa tingkat kredit macet. Selain itu juga manajer UKM sudah melakukan persiapan anggaran persediaan, memeriksa tingkat persediaan dan mengantisipasi jumlah persediaan, yang menunjukkan sudah terjadi EIM. Keputusan investasi (penempatan dana untuk modal kerja) paling direfleksikan oleh EIM, tetapi efisiensi tidak hanya dicapai oleh manajemen persediaan tetapi juga manajemen kas dan manajemen piutang. Secara psikologis, dilihat dari aspek psycohomotorik ditunjukkan dengan sudah dilakukan pembuatan anggaran kas, penentuan saldo yang ingin dicapai, perhitungan jumlah kas yang tersedia, pedoman kredit, dan kegiatan-kegiatan yang menunjang efisiensi dalam keputusan penempatan dana untuk modal kerja. Aspek cognitive ditunjukkan oleh pengambilan keputusan investasi penempatan dana untuk modal kerja yang direfleksikan oleh efisiensi dalam manajemen kas, piutang dan persediaan.

Kinerja financial paling membentuk kinerja perusahaan tetapi belum menghasilkan kinerja perusahaan yang optimal. Hal ini menggambarkan bahwa kinerja keuangan yang ada di UKM harus didukung oleh peningkatan penjualan sehingga menghasilkan keuntungan sesuai dengan yang diharapkan. Cara yang dapat dilakukan adalah peningkatan strategi promosi dengan menggunakan fasilitas internet melalui pembuatan website atau blog UKM, sehingga dapat memperluas pemasaran produk, yang harus diikuti dengan pengembangan produk baik dari segi peningkatan kuantitas maupun kualitas produk. Kinerja non financial UKM juga belum bisa dikatakan optimal. Hal ini disebabkan karena manajer UKM belum menyadari pentingnya peningkatan kualitas sumber daya manusia walaupun sudah mendapatkan pelatihan yang berkaitan dengan pengembangan UKM, tapi masih belum bisa menerapkan pada usahanya. Salah satu contoh yang paling sering dilakukan pada pengelolaan keuangan adalah ketidakdisiplinan manajer UKM dalam memisahkan uang pribadi dengan uang yang harus dikelola oleh perusahaan. Selain itu juga, UKM masih belum menerapkan sistem akuntansi yang baik dalam pengelolaan keuangan secara keseluruhan. Temuan ini memperluas hasil penelitian yang dilakukan oleh Hayajneh and Yassine (2011), Nyamao, et al. (2012), Eichholtz and Yonder (2011) dan Caballero, et al. (2011) walaupun dengan mengambil objek penelitian yang berbeda tetapi hasil temuannya sama yaitu ada pengaruh keputusan investasi terhadap kinerja perusahaan. Lebih jelasnya, hasil penelitian ini menyatakan keputusan investasi (penempatan dana untuk modal kerja) dengan indikator yaitu Efficiency of Cash Management (ECM), Efficiency of Receivables Management (ERM), dan Efficiency of inventory management (EIM ) berpengaruh signifikan terhadap kinerja perusahaan.

Teori prospek yang dikembangkan oleh Kahneman dan Tversky (1979) menunjukkan bahwa investor dihadapkan pada kemungkinan kerugian. Mereka akan lebih suka untuk memilih keputusan yang lebih berisiko dengan maksud untuk menghindari kerugian, walaupun mereka mungkin menghindar dari investasi secara 
keseluruhan. Kahneman dan Tversky (1979) juga menggambarkan bagaimana seseorang menilai keputusan yang mengandung risiko dan ketidakpastian melalui teori prospek yang selama ini banyak menjadi rujukan dalam studi keuangan perilaku. Menurut teori prospek, investor cenderung menilai pilihan keputusan investasi dalam konteks potensi keuntungan dan kerugian berdasarkan referensi tertentu misalnya harga beli. Hal ini memiliki implikasi bahwa investor akan selalu berhadapan dengan risiko.

Teori Manfaat Harapan (Expected Utility) yang diperkenalkan oleh Bernoulli pada abad ke 18, pada dasarnya mengatakan bahwa tidak semua orang akan memilih alternatif yang sama. Tergantung pada sikap masing-masing individu terhadap risiko. Teori Manfaat Harapan menyangkut pemilihan rasional alternatif keputusan yang menekankan bahwa orang mempunyai perilaku yang berbeda terhadap risiko. Sebagian orang berperilaku penghindar risiko dan berupaya untuk memaksimalkan manfaat dari setiap keputusan yang diambil. Bagi seorang yang berperilaku demikian, kurva fungsi manfaat berbentuk cekung, menunjukkan tambahan manfaat yang menurun untuk setiap tambahan pengeluaran. Sebagian yang lain bersikap netral terhadap risiko (risk neutral) dengan kurva manfaat yang berbentuk linier, serta sebagian yang lain lagi berperilaku penyuka risiko (risk taker) dengan kurva manfaat yang berbentuk cembung, menunjukkan peningkatan tambahan manfaat untuk setiap tambahan pengeluaran (Asri, 2013:32-33). Literatur psikologi menjuluki konsep manfaat harapan ini sebagai konsep yang menggambarkan harapan moral (moral expectation), bukan sekedar "harapan" yang dihitung secara matematis (mathematical expectation). Namun masih ada yang menganggap teori expected utility terlalu menyederhanakan permasalahan karena menganggap bahwa keputusan yang diambil seseorang seolah-olah hanya ditentukan oleh sikapnya terhadap risiko.

Kedua teori tersebut menggambarkan bahwa risk attitudes seseorang tidak sama. Ada beberapa faktor yang menyebabkan seseorang termasuk kedalam risk averse atau risk taker, yaitu jenis kelamin, usia, pengalaman dan tingkat pendidikan. Sikap terhadap risiko pengambil keputusan investasi di UKM berbeda dengan yang ada di pasar modal, karena tingkat keuntungan dan risiko dipasar modal jauh lebih besar dibandingkan dengan yang ada di UKM. Tegasnya, bisa dikatakan bahwa teori prospek dan teori expected utility yang banyak digunakan pada pasar modal menunjukkan perilaku risk attitudes yang bersifat irasional. Berbeda dengan perilaku risk attitudes yang ada di UKM yang bersifat rasional.

Dalam studi ini, variabel risk attitudes direfleksikan oleh 5 (lima) indikator, meliputi betting on self, capitalizing on opportunities, buying, no fear of losses dan stable returns. Kaitannya dengan betting on self, manajer UKM menunjukkan sudah melakukan kreasi sendiri, dengan keyakinan kreasi produk yang dihasilkan disukai dan diminati konsumen serta laku di pasaran. Dilihat dari segi capitalizing on opportunities manajer UKM sudah bisa memanfaatkan peluang dengan keyakinan peluang usaha yang ada menguntungkan dan tidak datang dua kali. Dalam buying atau kegiatan pembelian, menunjukkan bahwa pembelian yang dilakukan selalu diikuti dengan pemeriksaan secara detail terhadap bahan/perlengkapan yang sudah dibeli. Adapun kekurangan yang masih dirasakan oleh manajer UKM adalah belum bisa mengantisipasi kerugian dan merasa kerugian bisa saja terulang kembali serta pendapatan yang diterima belum dapat dikatakan stabil sehingga masih diperlukan usaha-usaha yang dapat meningkatkan pendapatan UKM. Salah satunya adalah peningkatan penjualan yang berpengaruh langsung terhadap pendapatan yang diterima. 
Variabel risk attitudes paling direfleksikan oleh indikator buying. Hal ini berarti manajer UKM berani mengambil risiko dalam pembelian untuk usahanya. Pada saat melakukan pembelian, manajer UKM selalu melakukan pemeriksaan secara detail terhadap bahan/perlengkapan yang sudah dibeli. Risk attitudes manajer sekaligus pemilk UKM menunjukkan sikap yang rasional. Hal ini ditunjukkan dengan adanya keyakinan mereka dalam mengambil risiko. Adapun yang melatarbelakangi manajer UKM dalam pengambilan risiko adalah pengalaman usaha di bidang gerabah sudah lebih dari 10 tahun. Selain itu juga adanya waktu yang cukup untuk mempertimbangkan keputusan apa yang akan diambil dan risiko yang dihadapi tidak seperti dipasar modal.

Keberanian manajer UKM mengambil risiko diikuti dengan menurunnya penempatan dana untuk modal kerja. Hal ini disebabkan oleh adanya kesadaran dari manajer UKM tentang pengelolaan usaha yang dilakukan selama ini belum bisa dikatakan optimal, sehingga menurunkan penempatan dana untuk modal kerja. Penempatan dana untuk modal kerja di UKM yang tidak didukung oleh pengelolaan usaha yang optimal mengakibatkan kinerja perusahaan, baik yang financial maupun non financial, tidak tercapai sesuai harapan. Ada beberapa hal yang mengakibatkan pengelolaan usaha pada UKM belum bisa optimal, salah satunya adalah tingkat pendidikan sebagian besar manajer UKM adalah tingkat menengah. Hal ini mengakibatkan pengambilan keputusan yang diambil untuk penempatan modal kerja tidak diikuti kedisiplinan dalam pengaturan keuangan perusahaan dalam hal ini UKM. Secara psikologis, dilihat dari aspek affective, sikap berani mengambil risiko yang diambil oleh manajer UKM di latarbelakangi oleh mereka sebagian besar laki-laki, usia masih produktif dan berpengalaman di bidang usaha gerabah lebih dari 10 (sepuluh) tahun.

\subsection{Tinjauan dari Segi Perspektif Perilaku (Cognitive, Affective dan Psychomotorik)}

Kemampuan sumberdaya manusia juga dapat dilihat dari perspektif perilaku. Menurut Bloom (1908) dalam Notoatmodjo (2003), Perspektif perilaku manusia terdiri dari tiga aspek yaitu cognitive, affective dan psychomotorik.

Aspek cognitive berorientasi pada Kemampuan berfikir yang mencakup kemampuan intelektual yang lebih sederhana, yaitu mengingat, sampai pada kemampuan memecahkan masalah. Dengan demikian aspek cognitive adalah subtaksomi yang mengungkapkan tentang kegiatan mental yang sering berawal dari tingkat pengetahuan sampai ke tingkat yang paling tinggi yaitu evaluasi. Pada penelitian ini aspek cognitive terlihat pada pengambilan keputusan investasi, yaitu penempatan dana untuk modal kerja. Dari hasil wawancara dengan manajer UKM, diperoleh informasi bahwa dalam menempatkan dana untuk modal kerja mereka sudah memperhitungkan kebutuhan kas, piutang dan persediaan. Modal kerja yang ada sebagian besar diinvestasikan untuk produksi gerabah. Keputusan investasi pada modal kerja yang dilakukan oleh manajer UKM bisa dikatakan tepat dilihat dari telah terjadinya efisiensi pada manajemen kas, piutang dan persediaan.

Aspek affective berkaitan dengan sikap dan nilai. Affective mencakup watak perilaku seperti perasaan, minat, sikap, emosi dan nilai. Dalam penelitian ini affective bisa digambarkan dari risk attitudes, mental acccounting dan overconfidence. Berdasarkan hasil penelitian, manajer UKM menunjukkan sikap yang berani mengambil risiko, mempunyai mental accounting yang kuat dan memiliki overconfidence.

Aspek psycohomotorik berkaitan dengan keterampilan (skill) atau kemampuan bertindak setelah seseorang menerima pengalaman belajar tertentu. Dalam penelitian 
ini, aspek tersebut bisa dilihat dari pembuatan daftar penagihan piutang, laporan piutang pembuatan anggaran kas, penentuan saldo yang ingin dicapai, perhitungan jumlah kas yang tersedia, pedoman kredit, dan kegiatan-kegiatan yang menunjang efisiensi dalam keputusan penempatan dana untuk modal kerja.

Dengan demikian bisa dikatakan bahwa secara psikologis manajer sekaligus pemilik UKM rasional dalam pengambilan keputusan investasi (penempatan dana untuk modal kerja). Beberapa faktor penyebabnya, yaitu: sebagian besar manajer sekaligus pemilik UKM adalah laki-laki, usia masih produktif dan pengalaman dalam bidang industri gerabah lebih dari 10 (sepuluh) tahun. Hal ini berbeda dengan yang ada di pasar modal, dimana keputusan untuk melakukan investasi atau portfolio, harus diputuskan dalam waktu yang singkat dengan risiko yang tinggi, sehingga kadangkala keputusan yang diambil oleh investor tidak sepenuhnya rasional (quasy rational), yang akhirnya akan berpengaruh terhadap hasil yang diperoleh.

\section{KESIMPULAN DAN SARAN}

\subsection{Kesimpulan}

Berdasarkan pengujian hipotesis, hasil pembahasan dan temuan penelitian, dapat dikemukakan beberapa kesimpulan sebagai berikut:

1. Keberanian manajer sekaligus pemilik UKM mengambil risiko diikuti dengan menurunnya penempatan dana untuk modal kerja. Hal ini disebabkan oleh adanya kesadaran dari manajer sekaligus pemilik UKM tentang pengelolaan usaha yang dilakukan selama ini belum bisa dikatakan optimal, sehingga menurunkan penempatan dana untuk modal kerja. Penempatan dana untuk modal kerja di UKM yang tidak didukung oleh pengelolaan usaha yang optimal mengakibatkan kinerja perusahaan, baik yang financial maupun non financial, tidak tercapai sesuai harapan. Ada beberapa hal yang mengakibatkan pengelolaan usaha pada UKM belum bisa optimal, salah satunya adalah tingkat pendidikan sebagian besar manajer UKM adalah tingkat menengah. Hal ini mengakibatkan pengambilan keputusan yang diambil untuk penempatan modal kerja tidak diikuti kedisiplinan dalam pengaturan keuangan perusahaan dalam hal ini UKM. Secara psikologis, dilihat dari aspek affective, sikap berani mengambil risiko yang diambil oleh manajer sekaligus pemilik UKM di latarbelakangi oleh mereka sebagian besar laki-laki, usia masih produktif dan berpengalaman di bidang usaha gerabah lebih dari 10 (sepuluh) tahun.

2. Sikap terhadap risiko yang diambil oleh manajer sekaligus pemilik UKM dalam mengelola usahanya tidak terlalu memengaruhi kinerja perusahaan. Ada "variabel mediasi“" yaitu keputusan investasi (penempatan dana untuk modal kerja), yang menghubungkan risiko dengan kinerja perusahaan, kemudian risk attitudes bisa mempengaruhi kinerja perusahaan. Dapat juga dijelaskan dari latar belakang sebagian besar responden yang mempunyai pendidikan tingkat menengah dan kepemilikan UKM yang sifatnya perorangan, yang berpengaruh dalam pengambilan keputusan. Keputusan yang diambil seringkali dengan informasi yang terbatas dan tanpa melakukan "sharing” dengan pihak lain.

3. Meningkatnya penempatan dana untuk modal kerja mengakibatkan semakin tinggi kinerja perusahaan yang dihasilkan oleh UKM. Keputusan Investasi (Penempatan dana untuk modal kerja) paling direfleksikan oleh Efficiency of inventory management (EIM). Kinerja financial paling membentuk kinerja perusahaan tetapi belum menghasilkan kinerja perusahaan yang optimal. Hal ini menggambarkan 
bahwa kinerja keuangan yang ada di UKM harus didukung oleh peningkatan penjualan sehingga menghasilkan keuntungan sesuai dengan yang diharapkan. Cara yang dapat dilakukan adalah peningkatan strategi promosi dengan menggunakan fasilitas internet melalui pembuatan website atau blog UKM, sehingga dapat memperluas pemasaran produk, yang harus diikuti dengan pengembangan produk baik dari segi peningkatan kuantitas maupun kualitas produk. Kinerja non financial UKM juga belum bisa dikatakan optimal. Hal ini disebabkan manajer UKM sekaligus pemilik belum menyadari pentingnya peningkatan kualitas sumber daya manusia walaupun sudah mendapatkan pelatihan yang berkaitan dengan pengembangan UKM, tapi masih belum bisa menerapkan pada usahanya.

Dengan demikian risk attitudes berpengaruh signifikan terhadap kinerja perusahaan melalui keputusan investasi penempatan dana untuk modal kerja. Selain itu juga bisa dikatakan bahwa secara psikologis manajer sekaligus pemilik UKM rasional dalam pengambilan keputusan investasi (penempatan dana untuk modal kerja). Hal ini dilatarbelakangi oleh sebagian besar manajer sekaligus pemilik UKM laki-laki, berusia masih produktif dan berpengalaman dibidangnya lebih dari 10 tahun.

Dapat ditegaskan bahwa teori prospek dan teori expected utility yang ditunjukkan oleh perilaku investor dalam pengambilan keputusan investasi di pasar modal bersifat irasional. Berbeda dengan perilaku manajer sekaligus pemilik UKM di dalam pengambilan keputusan investasi yang bersifat rasional. Perbedaan ini disebabkan oleh risiko yang dihadapi dan waktu yang dipergunakan dalam mempertimbangkan keputusan yang diambil.

\subsection{Saran-saran}

Berdasarkan pada hasil dan kesimpulan penelitian ini, dapat dikemukakan saransaran yang menjadi rekomendasi pada penelitian berikutnya.

1. Diharapkan penelitian mendatang tidak hanya melihat satu psychological bias yang termasuk dalam cognitive illusion saja, karena masih ada psychological bias yang lain mungkin saja juga berpengaruh dalam keputusan investasi dan kinerja perusahaan, seperti: representativeness, availability dan conservatism.

2. Penelitian yang akan datang diharapkan sampel penelitian tidak hanya terbatas pada UKM gerabah yang ekspor saja, karena masih banyak UKM ekspor yang berkembang di masyarakat, seperti UKM kerajinan bambu dan kayu.

3. Penelitian yang akan datang diharapkan mengkaji secara mendalam penyebab pengelola UKM belum bisa mengelola keuangan dengan baik, walaupun sudah mendapatkan pelatihan yang berkaitan dengan pengelolaan keuangan.

4. Penelitian yang akan datang, diharapkan tidak saja pada profit organization tapi juga pada non profit organization, aparat pemerintah dan rumah tangga, sehingga bisa diketahui bagaimana keuangan perilaku pada objek penelitian yang lain. 


\section{DAFTAR PUSTAKA}

Asri, Marwan. 2013. Keuangan Keperilakuan. Edisi Pertama. BPFE-UGM. Yogyakarta.

Bell, D. 1992. Regret in Decision Making Under Uncertainty. Operation Research, 30 (5).

Caballero, Sonia Banos; Teruel, Pedro J. Garcia and Solano, Pedro Martinez. 2011. Working Capital Management, Corporate Performance, and Financial Constraint. Dep. Management and Finance, Faculty of Economics and Business, University of Murcia, Murcia (SPAIN).

Coleman, Les. 2007. Risk and Decision Making by Financing Executives: A Survey Study. International Journal of Managerial Finance. Vol. 3, No.1.

De Bondt, W. et al. 2008. Behavioral Finance: Quo Vadis?. Journal of Applied Finance; Fall 2008; 18, 2; ABI/INFORM Research.

Ferdinand, Augusty. 2011. Metode Penelitian Manajemen. BP. UNDIP. Semarang.

Forbes, William.2009. Behavioural Finance. First Edition. John Wiley \& Sons Ltd.

Gumanti, Ary Tatang. 2009, Behavior Finance: Suatu Telaah. Usahawan No. 1/Th, XXXVIII.

Hayajneh and Yassine. 2011. The Impact of Working Capital Efficiency on Profitability-an Empirical Analysis on Jordanian Manufacturing Firm, International Research Journal of Finance and Economics, ISSN 1450-2887 Issue 66.

Helliar. Power and Sinclair.1. 2005. Manager "Irrationallty" in financing Decision Making. Managerial Finance. Vol. 3, Number 4.

Idrus, M. Syafiie. 1999. Strategi Pengembangan Kewirausahaan (Entreprenuership) dan Peranan Perguruan Tinggi dalam Rangka Membangun Keunggulan Bersaing (Competitive Advantage) Bangsa Indonesia pada Millenium Ketiga, Makalah tidak dipubilkasikan, Universitas Brawijaya.

Iramani dan Bagus, Dhyka. 2008. Faktor-faktor Penentu Perilaku Investor dalam transaksi Saham di Surabaya. Jurnal Aplikasi Manajemen, Vol. 6, No. 3.

Jermias, Johnny and Gani, Lindawati. 2005. Ownership Structure, Contingent-fit, and Business-unit Performance: A Research Model and Empirical Evidence. The International Journal of Accounting, vol. 40.

Lammers. Willebrands and Hartog, 2010, Risk Attitudes and Profit among Small Enterprises in Nigeria. Tinbergen Institute Paper TI 2010-053/3

Lintner, G. 1998. Behavioral Finance: Why Investors Make Bad Decisions. The Planner, 13 (1), 7-8. Vol. 68, No.4.

Lipe.1993. Analyzing the Variance Investigation decision: The Effect of Outcomes, Mental Accounting, and Framing. The Accounting Review. Vol. 68, No.4.

Nyamao; Patrick; Martin; Odondo and Simeyo. (2012). Effect of working capital management practices on financial performance: A study of small scale enterprises in Kisii South District, Kenya. African Journal of Business Management, Vol. 6.

Pompian, Michael M.2006. Behavioral Finance and Wealth Management. John Wiley \& Sons, Inc.

Ramiah; Zhao; Graham and Moosa. 2012. Behavioural Aspects of Working Capital Managers. School of Economics, Finance and Marketing, RMIT University, Australia. 
Supramono; Kaudin; Mahastuti dan Damayanti. 2010. Desain Penelitian Keuangan Berbasis Perilaku. Penerbit: Pusat Studi Keuangan Berbasis Perilaku Fakultas Ekonomi UKSW Salatiga.

Solimun. 2012. Pemodelan Persamaan Struktural: Generalized Structured Component Analysis GSCA. Materi Pelatihan Statistic Multivariat. Fakultas MIPA. Universitas Brawijaya.

Susai, and Moriyasu. 2007. Consistency of Risk Attitude and other Investment Behaviour of Japanese Professional Fund Managers: Questionnaire-based Analysis. Working Paper Series. Waseda University Institute of Finance.

Sugiyono. 2008. Metode Penelitian Bisnis (Pendekatan Kuantitatif, Kualitatif dan $R \&$ $D)$, Bandung: CV. Alfabeta.

Trinugroho, dan Sembel. 2011. Overconfidence and Excessive Trading Behavior: An Experimental Study. International Journal of Business and Management, Vol. 6, No. 7.

Tversky, A, and Brack, Davis.1995. The Psychology of Decision Making. Behavioral Finance and Decision Theory in Investment Management. AIMR. Charlottesville.USA.

Vos, Yeh, Carter and Tagg. 2007. The happy story of small business financing. Journal of Banking and Finance, Vol. 31.

Weston, J. Fred and Copeland, Thomas E. 1986. Managerial Finance. CBS International Edition. CBS College Publishing. New York.

http://www.Diskop.Padang.go.id. Diakses Januari 2016

http://www.ekonomi.kompasiana.com/moneter/2012/03/15/psikologi-keuangan-1 Di akses Januari 2016 